\title{
Effects of Acanthus ebracteatus Vahl on tumor angiogenesis and on tumor growth in nude mice implanted with cervical cancer
}

This article was published in the following Dove Press journal:

Cancer Management and Research

22 August 2012

Number of times this article has been viewed

\author{
Taksanee Mahasiripanth' \\ Sanya Hokputsa ${ }^{2}$ \\ Somchai Niruthisard ${ }^{3}$ \\ Parvapan Bhattarakosol ${ }^{4}$ \\ Suthiluk Patumraj ${ }^{5}$ \\ 'Inter-Department of Physiology, \\ Chulalongkorn University, Bangkok, \\ Thailand; ${ }^{2}$ Research and Development \\ Institute, Government Pharmaceutical \\ Organization, Bangkok, Thailand; \\ ${ }^{3}$ Obstetrics and Gynecology \\ Department, ${ }^{4}$ Department of \\ Microbiology, ${ }^{5}$ Center of Excellence \\ for Microcirculation, Faculty of \\ Medicine, Chulalongkorn University, \\ Bangkok, Thailand
}

Purpose: The aim of this study was to examine the effects of the crude extract of Acanthus ebracteatus Vahl (AE) on tumor growth and angiogenesis by utilizing a tumor model in which nude mice were implanted with cervical cancer cells containing human papillomavirus 16 DNA (HPV-16 DNA).

Materials and methods: The growth-inhibitory effect of AE was investigated in four different cell types: CaSki (HPV-16 positive), HeLa (HPV-18 positive), hepatocellular carcinoma cells (HepG2), and human dermal fibroblast cells (HDFs). The cell viabilities and $\mathrm{IC}_{50}$ values of $\mathrm{AE}$ were determined in cells incubated with $\mathrm{AE}$ for different lengths of time. To conduct studies in vivo, female BALB/c nude mice (aged 6-7 weeks, weighing 20-25 g) were used. A cervical cancer-derived cell line (CaSki) with integrated HPV-16 DNA was injected subcutaneously $\left(1 \times 10^{7}\right.$ cells $\left./ 200 \mu \mathrm{L}\right)$ in the middle dorsum of each animal (HPV group). One week after injection, mice were fed orally with AE crude extract at either 300 or $3000 \mathrm{mg} / \mathrm{kg}$ body weight/day for 14 or 28 days (HPV-AE groups). Tumor microvasculature and capillary vascularity were determined using laser scanning confocal microscopy. Tumor tissue was collected from each mouse to evaluate tumor histology and vascular endothelial growth factor (VEGF) immunostaining.

Results: The time-response curves of $\mathrm{AE}$ and the dose-dependent effect of $\mathrm{AE}$ on growth inhibition were determined. After a 48-hour incubation period, the $\mathrm{IC}_{50}$ of $\mathrm{AE}$ in CaSki was discovered to be significantly different from that of HDFs $(P<0.05)$. A microvascular network was observed around the tumor area in the HPV group on days 21 and 35. Tumor capillary vascularity in the HPV group was significantly increased compared with the control group $(P<0.001)$. High-dose treatment of AE extract (HPV-3000AE group) significantly attenuated the increase in VEGF expression and tumor angiogenesis in mice that received either the 14- or 28-day treatment period $(P<0.001)$.

Conclusion: Our novel findings demonstrated that AE crude extract could inhibit cervical cancer growth, VEGF expression, and angiogenesis in a CaSki-cell transplant model in mice.

Keywords: Acanthus ebracteatus Vahl, tumor angiogenesis, VEGF, CaSki cell-implanted nude mice, capillary vascularity, laser scanning confocal microscopy

\section{Introduction}

Cervical cancer, a malignant tumor that occurs in the cervical area of the uterus, is the second most common type of cancer in women worldwide. ${ }^{1}$ Presently, it is clear that persistent human papillomavirus (HPV) infection of the epithelial cell within the cervical mucosa significantly contributes to the development and maintenance of cancer. More than 100 different types of HPV have been reported, and approximately 20 HPV types are associated with cervical cancer. HPV DNA is found in nearly all
Correspondence: Suthiluk Patumra Department of Physiology, Faculty of Medicine, Chulalongkorn University, Bangkok 10330, Thailand Tel +662 2527854 ext 2032

Fax +66 22527854 ext 6032 Email suthilukp@yahoo.com 
cervical cancer tissue $(>99.7 \%),{ }^{2,3}$ and the prominent types appear to be HPV-16, 18, 31, and $45 .{ }^{4}$ The high-risk types of HPV (HR-HPV) are, HPV-16, and HPV-18, which account for approximately $50 \%$ and $20 \%$ of all cervical cancers, respectively. ${ }^{5,6} \mathrm{HR}-\mathrm{HPV}$ contains two critical oncogenes, E6 and E7, which are involved in the carcinogenesis of host cells. The E6 and E7 oncoproteins bind to the cellular tumorsuppressor proteins $\mathrm{p} 53$ and $\mathrm{pRb}$, respectively. These interactions result in the degradation of active p53 and interference with $\mathrm{pRb}$ function, which then transform the precancerous lesion into a malignant cancer. ${ }^{7}$

Currently, there exists evidence to support a major role for HPV in the process of angiogenesis during the early stages of cervical cancer. High expression of vascular endothelial growth factor (VEGF), a potent angiogenic factor, has been found documented in all stages of cervical cancer lesions. ${ }^{8-15}$ HPV E6 promotes VEGF-dependent angiogenesis during the growth and development of cervical cancer. ${ }^{16-18}$ Moreover, it has been reported that the upregulation of VEGF expression results from HPV E6-induced p53 degradation. ${ }^{19}$ In addition, both E6 and E7 induce VEGF expression via direct triggering of the VEGF promoter, ${ }^{16,17}$ which is mediated through enhancing the hypoxia-inducible factor- $1 \alpha(\mathrm{HIF}-1 \alpha)$ protein expression in HPV-16-positive cervical cancer cells. ${ }^{18}$

During the last decade, there have been a number of research studies reporting that the Thai medicinal plant Acanthus ebracteatus Vahl (AE) (family Acanthaceae; English name, Sea Holly; Thai name, "ngueak pla mo") has antitumor potential. AE is a spiny mangrove herb that is used in a ayurvedic folk medicine and is commonly distributed in Southeast Asia. It is composed of several chemical constituents, including alkaloids, flavonoids, tritepenoids, sterols, aliphatic glycosides, lignans, phenolic glycosides, quaternary amino acids, and polysaccharides. ${ }^{20-24}$ A number of studies conducted on this plant and others of its species identified bioactive components that posses special pharmacological activities, including antimicrobial, immunopotentiating, hepatoprotective, antioxidative, anti-inflammatory, antimutagenicity, and anticarcinogenic activities. $^{25-31}$

Interestingly, studies employing different experimental animal models have reported that the extract from AE can delay the onset of carcinogenesis, inhibit hepatocarcinogenesis, inhibit tumor progression, and greatly decrease tumor growth. ${ }^{24,32-34}$ It has been suggested that the cytotoxic effects of AE on different types of cancer may result from this plant's bioactive compounds, including $\beta$-sitosterol, stigmasterol, lupeol, and benzoxazoline-2-one. ${ }^{35-38}$
The antitumor effect of $\mathrm{AE}$ has not been studied in HPV-16-positive cervical carcinoma cells. Moreover, though it is well known that $\mathrm{AE}$ crude water-soluble polysaccharides inhibit VEGF, ${ }^{23,38}$ a key regulator of angiogenesis, there currently exist no experimental data addressing the possible mechanism by which AE inhibits tumor angiogenesis.

Therefore, the present study is the first to demonstrate the effects of AE on tumor growth, tumor angiogenesis, and VEGF expression using a tumor model in which HPV-16positive human cervical carcinoma cells were implanted into nude mice.

\section{Materials and methods Preparation of A. ebracteatus Vahl crude extract}

The crude extract of AE was prepared by the Medicinal Plant Analytical Development Section, Research and Development Institute, Government Pharmaceutical Organization (GPO), Thailand. Briefly, fresh leaves and stems of AE were chopped into small pieces and then sun-dried until a residual moisture content of $16.8 \%$ weight/weight was obtained. The dried matter was then boiled with distilled water $(1 \mathrm{~kg}$ dried matter per $20 \mathrm{~L}$ water) twice. After filtration, the solution was dried by spraying it until it became powder ( $15 \mathrm{~kg}$ of ground dried leaves and stems: $1800 \mathrm{~g}$ of powder extract). The light creamy-white powder was then kept in foil packages ( 20 g per pack) with humidity absorbance. The powder was dissolved in distilled water for use in each experiment. ${ }^{23,39}$

\section{Cell line cultivation}

Three human cancer cell lines and one normal cell line were used in this study. Two human cervical carcinoma cell lines, which contain integrated HPV-DNA, were used: CaSki (HPV-16-positive) and HeLa (HPV-18-positive). HepG2, hepatocellular carcinoma cells, were also used. These three cancer cell lines were obtained from the American Type Culture Collection (Manassas, VA). The human dermal fibroblast cells, or HDFs, were purchased from Cell Applications (San Diego, CA). All cancer cells were grown in minimum essential medium (Gibco, Gaithersburg, MD) supplemented with $10 \%$ heat-inactivated fetal bovine serum (Invitrogen, CA, USA), an antibiotic-antimycotic mixture of penicillin (50 unit/mL) and streptomycin $(50 \mu \mathrm{g} / \mathrm{mL})$ (Bio Basic, Markham, Canada) and $2 \mathrm{mM}$ L-glutamine. HDF cells were maintained in fibroblast growth medium (Cell Applications) supplemented with a low-serum-growth supplement. Cells were cultured at $37^{\circ} \mathrm{C}$, and $5 \% \mathrm{CO}_{2}$ in a humidified incubator. 
The medium was replaced with fresh medium every other day, and cells were subcultured when they reached $80 \%$ confluence to maintain cell growth in the log phase. Before use, cells were trypsinized using $0.025 \%$ trypsinEDTA (Invitrogen).

\section{Cell proliferation assay}

The effects of AE crude extract on cell growth were examined using the 3-(4,5-dimethylthiazol-2-yl)-2,5-diphenyltetrazolium-bromide assay (MTT) (Sigma-Aldrich, St Louis, MO). Cells were divided into the control group (untreated) and treatment groups, which received different concentrations of the AE crude extract $\left(10^{-3}-10^{4} \mu \mathrm{g} / \mathrm{mL}\right)$.

Briefly, $0.025 \%$ trypsin-EDTA was used to detach cells and prepare single-cell suspensions. Cells were then seeded into 96-well plates $\left(1 \times 10^{4}\right.$ cells per well in $100 \mu \mathrm{L}$ of complete culture medium). The cells were allowed to grow for 24 hours at $37^{\circ} \mathrm{C}$ in a humidified incubator with $5 \% \mathrm{CO}_{2}$ atmosphere. On the following day, the medium was removed and replaced with complete medium containing the crude extract of $\mathrm{AE}\left(10^{-3}-10^{4} \mu \mathrm{g} / \mathrm{mL}\right.$ in a total volume of $\left.100 \mu \mathrm{L} / \mathrm{well}\right)$, but for the control group, only medium was added.

After incubation for 21, 48, or 72 hours, the medium was aspirated and $100 \mu \mathrm{L}$ of $0.5 \mathrm{mg} / \mathrm{mL}$ MTT in serumfree medium was added into each well. The plate was then incubated for 4 hours at $37^{\circ} \mathrm{C}$ in a humidified incubator with $5 \% \mathrm{CO}_{2}$. After incubation, the MTT formazan, which is the metabolic product produced by viable cells, appeared as dark crystals in the bottom of the wells. The MTT solution was carefully removed from each well to prevent disruption of the cell monolayer and then was replaced with $150 \mu \mathrm{L}$ of $99.9 \%$ dimethylsulfoxide (Sigma-Aldrich). To ensure thorough dissolving of the formazan crystals, each plate was placed on a shaking table for 5 minutes at room temperature. A purple solution was visible at this stage, and the optical density (OD) of each plate was read by an enzyme-linked immunosorbent assay plate reader (Bio-Rad Laboratories, Hercules, CA) at a wavelength of $540 \mathrm{~nm}$. The MTT assay was repeated in at least 3 independent experiments.

The inhibitory effect of AE on cell proliferation was calculated by determining the percentage of living cells at each time interval: (OD of AE-treated sample - OD of blank $) /(\mathrm{OD} \text { of untreated control - OD of blank })_{\mathrm{t}} \times 100 \%$. Dose-response curves were obtained for each cell type by plotting the percentage of growth inhibition versus the AEextract concentrations. After 48 hours of incubation with AE, the nonlinear regression equation was used to calculate the half-maximal inhibitory concentrations $\left(\mathrm{IC}_{50}\right.$ values; fitting logistic-sigmoidal model) using Origin version 5.0 software (MicroCal Northampton, MA).

\section{Experimental animal preparation}

Inbred female BALB/c nude mice (body weight 20-25 g) were obtained from the National Laboratory Animal Center, Salaya Campus, Mahidol University, Nakornpathom, Thailand. All animal experiments were conducted according to the Ethical Guidelines for the Uses of Animals by The National Research Council of Thailand (1999) and were approved by the Institutional Animal Care and Use Committee of Chulalongkorn University, Thailand. The mice were housed in a specific pathogen- and germ-free environment where the temperature was maintained at $25^{\circ} \pm 3^{\circ} \mathrm{C}$ with $60 \%-70 \%$ air humidity and a 12 -hour light-dark cycle. During the experiment, the mice were fed with standard laboratory chow and sterile water ad libitum.

The mice were divided into four groups: (1) control mice that received distilled water (Con; $n=5)$, (2) HPV-16implanted mice that received distilled water (HPV-Veh; $\mathrm{n}=8$ ), (3) HPV-16-implanted mice that received AE $300 \mathrm{mg} / \mathrm{kg}$ body weight (HPV-300AE, $\mathrm{n}=8$ ), and (4) HPV-16-implanted mice that received AE $3000 \mathrm{mg} / \mathrm{kg}$ body weight (HPV-3000AE; $\mathrm{n}=8$ ). The AE supplementation began 24 hours after the inoculation of CaSki cells and continued for 14 or 28 days.

The HPV-implanted mice were prepared according to the procedure reported previously by Lertworapreecha et al in $2009 .{ }^{40}$ For the HPV group, CaSki cells $\left(1 \times 10^{7}\right.$ cells $/ 200 \mu \mathrm{L}$, viability $>95 \%$ ) were injected into the subcutaneous layer of dorsal skin in mice. Control mice received $200 \mu \mathrm{L}$ of minimum essential medium only, which was equivalent to the volume injected into the HPV mice. All mice were then housed at one animal per cage until the end of the experiment.

All procedures were performed under aseptic conditions. To confirm tumorigenesis, at the end of each experiment a tissue sample from the dorsal skin area where the cancer cells were previously injected was collected for histological examination. Hematoxylin and eosin-stained specimens were evaluated by a pathologist in the Pathological Division, Department of Obstetrics and Gynecology, Faculty of Medicine, Chulalongkorn University.

\section{Tumor microvasculature imaging}

The experiments were performed on days 14 and 21 after either vehicle or AE treatments. The mice were anesthetized with an intraperitoneal injection of sodium pentobarbital $(50 \mathrm{mg} / \mathrm{kg}$ body weight). A catheter was inserted into the jugular vein to inject fluorescence tracers 
(5\% fluorescein isothiocyanate-labeled dextran [FITCdextran], $\mathrm{MW}=200000,0.5 \%$ ) (Sigma-Aldrich).

The tumor microvascular network was observed using a laser scanning confocal microscope system (Eclipse E800 C1; Nikon, Tokyo, Japan). By cutting and including the dorsal skin around the tumor mass, the skin and the adjacent tumor mass could then be turned inside out and fixed with modeling wax on a plate. For visualization of the microvascular lumen, a bolus of $0.1 \mathrm{~mL} 5 \%$ FITC-dextran was injected into the jugular vein 5 minutes prior to imaging. During the experiment, the fluorescent images were obtained for analysis of the capillary vascularity within the tumor-bearing area using the image analysis software Image-Pro Plus 6.0 (Media Cybernetics, Bethesda, MD).

\section{Determination of capillary vascularity}

From the confocal microvascular images, the capillary vascularity (CV) of each mouse was determined using Global Lab Image/2 (Data Translation, Marlboro, MA) software. The software calculated the $\mathrm{CV}$ in three regions of interest (ROIs) from one fluorescent image (frame) for each mouse. The RGB images were converted into binary images, and vascular pixels and perivascular pixels were differentiated from each other based on gray-scale intensity. The CV was defined as the number of microvessel pixels divided by the total number of pixels within the ROI, as described by Viboolvorakul et al in 2009. ${ }^{41}$ Accordingly, averaging CV over three ROIs was performed, and the mean CV value in each group was used as an index of tumor angiogenesis. Each ROI was selected to cover only capillary networks with a diameter of less than $15 \mu \mathrm{m} .{ }^{42}$

\section{Determination of tumor volume and histopathological examination}

When the tumor microvasculature study was completed, mice were killed and the tumor masses were excised carefully. Tumor size was measured by using a Vernier caliper (VWR, St Louis, MO). Tumor volume was calculated using the ellipsoid volume formula: volume $\left(\mathrm{mm}^{3}\right)=\pi / 6$ (length) $\times$ (width) $\times$ (height). ${ }^{43}$ The tumor mass was then fixed with neutral buffer formalin (4\% formalin, $0.4 \% \mathrm{NaH}_{2} \mathrm{PO}_{4}$, $0.65 \% \mathrm{Na}_{2} \mathrm{HPO}_{4}$ ) for further evaluation of histopathological changes. The formalin-fixed, paraffin-embedded tissue samples were cut into $5-\mu \mathrm{m}$ sections using a microtome with a disposable blade. The sliced tissue was fixed onto a slide and stained with hematoxylin and eosin using automatic tissue staining (Autostainer XL; Leica Microsystems, Wetzlar, Germany). The establishment of cervical carcinoma was confirmed by a trained pathologist (Pathological Division, Department of Obsteric and Gynecology, Faculty of Medicine, Chulalongkorn University).

\section{Determination of VEGF expression}

Immunostaining was performed on paraffin-embedded $5-\mu \mathrm{m}$-thick tumor sections. Sections were deparaffinized, hydrated, blocked for endogenous peroxidase using $3 \% \mathrm{H}_{2} \mathrm{O}_{2} /$ $\mathrm{H}_{2} \mathrm{O}$, and subsequently incubated with antigen Retrieval Solution EDTA buffer (BD Pharmingen, San Diego, CA) in a $95^{\circ} \mathrm{C}-99^{\circ} \mathrm{C}$ water bath at $\mathrm{pH} 8$ for 40 minutes.

Nonspecific background was blocked by the application of $200 \mu \mathrm{L}$ of $3 \%$ normal horse serum. Then, $200 \mu \mathrm{L}$ of the anti-VEGF antibody (1:100; Santa Cruz Biotechnology, Santa Cruz, CA) was applied to tissue sections, followed by incubation at $4{ }^{\circ} \mathrm{C}$ overnight. After washing with phosphatebuffered saline ( $\mathrm{pH} 7.4), 200 \mu \mathrm{L}$ of visualization reagents (Envision) were applied to the tissue sections, which were then incubated at room temperature for 30 minutes. Color was developed using 3,3'-diaminobenzidine tetrahydrochloride and the slides were then counterstained with hematoxylin and mounted with resinene. Negative control slides were generated by replacing the primary antibody with phosphate-buffered saline and normal rabbit serum. Known immunostaining-positive slides were used as positive controls.

The cells staining positively for VEGF were observed and recorded using a digital camera (DS-Fi1-L2; Nikon) and image software (NIS-Elements Basic Research, Nikon). The quantitative analysis of VEGF expression was performed using Image-Pro Plus 6.1 software. VEGF-positive cells exhibited brown-yellow particles in the cytoplasm, and the percentage of VEGF expression was defined by determining the proportion of VEGF-positive staining area per total ROI area. ${ }^{44}$

\section{Statistical analysis}

All results are expressed as the mean \pm standard error of mean. Statistical analyses were performed by one-way analysis of variance using SPSS version 16.0 (IBM, Armonk, NY). The difference between means was considered statistically significant when the probability level ( $P$-value) was less than 0.05 .

\section{Results}

\section{Effects of $A E$ on cell proliferation}

The time-response curves of AE crude extract were generated by plotting the percentage of cell viability versus the 
concentrations of $\mathrm{AE}$ after three different incubation periods (24, 48, and 72 hours), as shown in Figure 1.

In Table 1 , the $\mathrm{IC}_{50}$ of $\mathrm{AE}$ in each cell type was calculated using the nonlinear regression equation (fitting logistic sigmoidal model). The results indicate that the dose-dependent effect of $\mathrm{AE}$ on growth inhibition, as well as the $\mathrm{IC}_{50}$, were significantly different between CaSki cells and HDFs $(P<0.05)$.

\section{Effects of AE on tumor volume and histopathological examination}

One week after inoculation with CaSki cells, a tumor bud could be observed, and over time it enlarged continuously. Table 2 shows the mean values of tumor volume for each group. These data indicate that the tumor volume of the HPV3000AE group was significantly less than the tumor volume of the HPV-Veh group $(P<0.05)$. These results indicate that high-dose treatment of AE crude extract may significantly inhibit or delay cervical carcinoma growth.
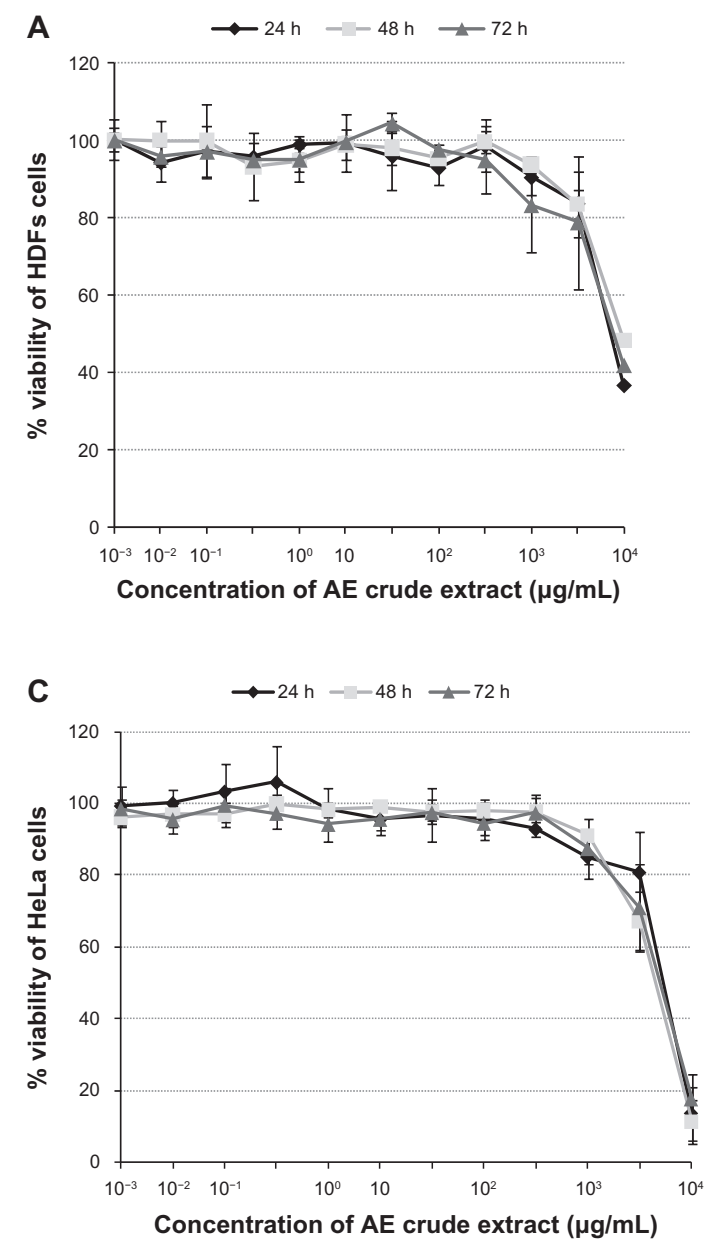

Following excision of the tumor nodule, the results of histological study confirmed the presence of a large deposit of malignant tumor deep below the skin of the mouse, between bundles of skeletal muscle. The morphological features of the cancer cells confirmed that they were squamous cell carcinomas, which are characterized by irregular round nuclei, small nucleoli, and a pale pink cytoplasm. In addition, these histological results seem to support that high-dose treatment of AE crude extract may inhibit or delay cervical carcinoma growth (Figure 2).

\section{Antiangiogenic activity of $\mathrm{AE}$}

Figure 3 shows confocal fluorescent images of the microvasculature of the tumors collected from the HPV groups on day 14 or day 28 , with or without AE treatment. The laser confocal microscopic images revealed a large number of microvascular networks around the tumor masses in the HPV-16 group (Figure 3A and B). In addition, the images indicated that the tumor microvascular ultrastructure
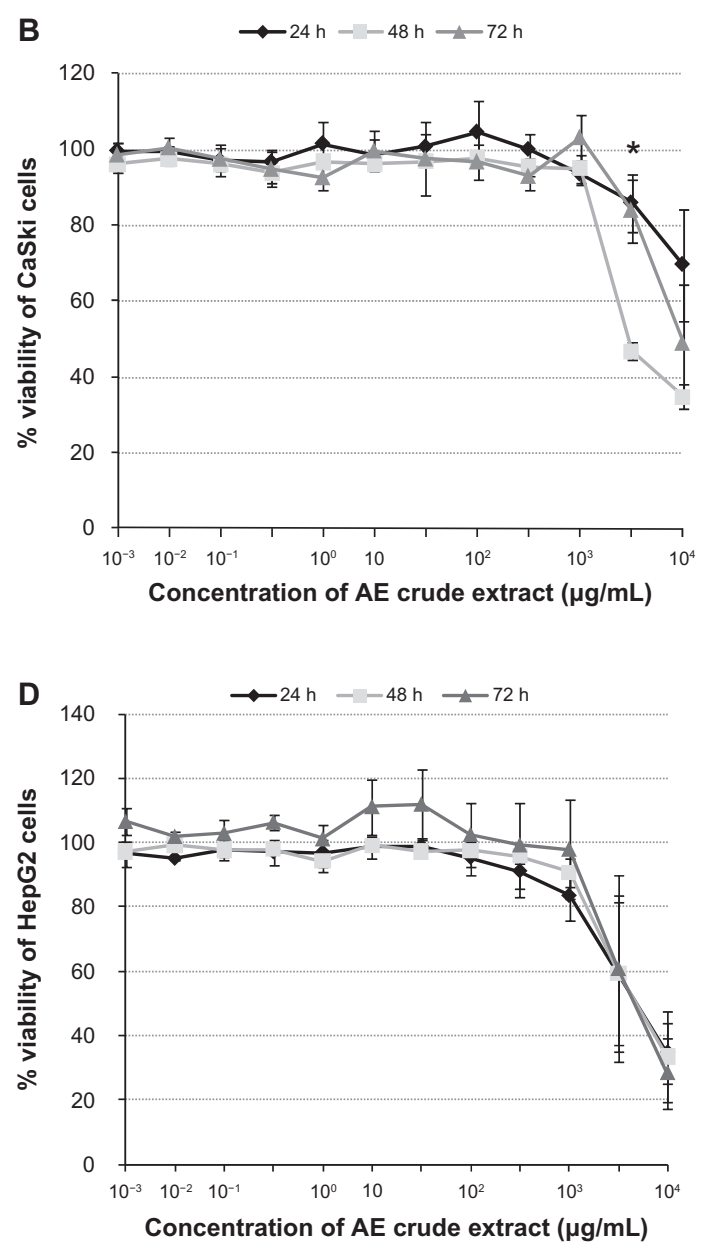

Figure I The percent cell viability of HDFs (A), CaSki (B), HeLa (C), and HepG2 cells (D) when treated with Acanthus ebracteatus Vahl at different concentrations $\left(10^{-3}-10^{4} \mu \mathrm{g} / \mathrm{mL}\right.$ with total volume $100 \mu \mathrm{L} /$ well) after $24-$, $48-$, and 72 -hour incubations.

Abbreviations: HDFs, human dermal fibroblast cells. 
Table I The half maximal inhibitory concentration $\left(\mathrm{IC}_{50} \mu \mathrm{g} / \mathrm{mL}\right)$ of Acanthus ebracteatus Vahl (AE) crude extract in three cancer cell lines (CaSki, HeLa, HepG2) and one normal cell type (human dermal fibroblast cells [HDFs]) after incubation with AE for 48 hours

\begin{tabular}{llll}
\hline $\begin{array}{l}\text { Cell } \\
\text { types }\end{array}$ & $\begin{array}{l}\text { No of } \\
\text { experiment }\end{array}$ & IC $_{50}(\mu \mathrm{g} / \mathrm{mL})$ & $\begin{array}{l}\text { Mean of } \\
\mathrm{IC}_{50}(\mu \mathrm{g} / \mathrm{mL})\end{array}$ \\
\hline CaSki & $\mathrm{I}$ & $4290.11 \pm 333.06$ & $4984.90 \pm 498.72^{*}$ \\
& 2 & $4712.45 \pm 852.03$ & \\
& 3 & $5952.04 \pm 595.8 \mathrm{I}$ & \\
HeLa & $\mathrm{I}$ & $7009.56 \pm 434.40$ & $6072.50 \pm 573.29^{\text {ns }}$ \\
& 2 & $5031.74 \pm 33.90$ & \\
& 3 & $6176.10 \pm 421.22$ & \\
HepG2 & 1 & $2263.06 \pm 391.99$ & $6419.50 \pm 2282.62^{\text {ns }}$ \\
& 2 & $7708.35 \pm 534.24$ & \\
& 3 & $9988.64 \pm 1286.13$ & \\
HDFs & 1 & $7121.10 \pm 296.88$ & $7382.40 \pm 221.05$ \\
& 2 & $7822.03 \pm 599.39$ & \\
& 3 & $7203.23 \pm 351.64$ & \\
\hline
\end{tabular}

Notes: "Significantly different compared with HDFs $(P<0.01)$, as determined by the

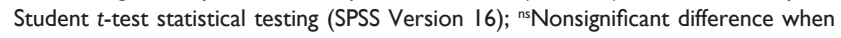
compared with HDFs. Data are expressed as the mean \pm standard error of mean, $n=3$ ( $n=$ number of independent experiments, which were performed in triplicate). The $\mathrm{IC}_{50}$ values were determined at 48 hours using the nonlinear regression equation (fitting logistic-sigmoidal model) and Microcal Origin version 5.0 software program. Abbreviation: IC50, half maximal inhibitory concentration.

contained pathological features, including abrupt changes in diameter, tortuosity, and hyperpermeability. From the confocal laser scanning images, the tumor $\mathrm{CV}$ was evaluated using digital-image analysis, as previously described. The results demonstrate that the neocapillary densities were significantly increased in the HPV-Veh group on days 14 and 28 (CV 56.28\% $\pm 1.43 \%$ and $71.52 \% \pm 3.51 \%$, respectively; $P<0.01)$, when compared with the aged-matched control group $(22.58 \% \pm 0.39 \% ; P<0.01)$ (Figure 4$)$. Interestingly, the high-dose $(3000 \mathrm{mg} / \mathrm{kg})$ treatment of AE induced a significant decrease in the tumor $\mathrm{CV}$ on both day 14 and day $28(P<0.05)$ (Figure 4).

\section{Effects of AE on VEGF expression}

Figure 5 shows the results of immunoreactivity of VEGF expression taken from control, HPV, and HPV treated

Table 2 Tumor volume of the tumor nodules excised from each human papillomavirus (HPV) group

\begin{tabular}{lll}
\hline Groups & Tumor volume $\left(\mathbf{m m}^{3}\right)$ & \\
\cline { 2 - 3 } & $\begin{array}{l}\text { At day I4 } \\
\text { after AE treatments }\end{array}$ & $\begin{array}{l}\text { At day } 28 \\
\text { after AE treatments }\end{array}$ \\
\hline HPV-Veh & $103.79 \pm 11.69(n=4)$ & $235.98 \pm 7.57(n=5)$ \\
HPV-300AE & $94.89 \pm 9.50^{n s}(n=3)$ & $245.36 \pm 36.26^{\text {ns }}(n=4)$ \\
HPV-3000AE & $62.37 \pm 16.56^{*}(n=5)$ & $155.77 \pm 7.55^{*}(n=4)$ \\
\hline
\end{tabular}

Notes: *Significant difference from HPV-Veh group $(P<0.05)$; ${ }^{\text {ns Nonsignificant }}$ difference from HPV-Veh group $(P<0.05)$. Data expressed as the mean \pm standard error; volume $\left(\mathrm{mm}^{3}\right)=\pi / 6$ (length) $\times($ width $) \times$ (height) ${ }^{43}$

Abbreviations: Veh, vehicle; AE, Acanthus ebracteatus Vahl crude extract. with AE. Table 3 shows the results of VEGF expression in control and CaSki-implanted mice. It indicated that CaSkiimplanted mice had significant VEGF expression more than the control group. Interestingly, it also indicated that AE crude extract could inhibit VEGF expression in a dosedependent manner.

\section{Discussion}

In the present study, the innovation of using an established mouse model for studying HPV-16-containing CaSki cervical cancer cells was successfully achieved. The technique we used here was different than the technique we used in our previous models of HeLa cell-derived cervical cancer in mice. ${ }^{40}$ In this study, we performed subcutaneous injection of CaSki cells to induce a cervical cancer nodule on the mouse's dorsal skin. A total of $10^{7} \mathrm{CaSki}$ cells are required to establish a tumor nodule at dorsal skin within 1 week after inoculation. According to the report from the pathologist, tumors generated using this model displayed features of malignant tumors, and in particular exhibited hallmarks of squamous cell carcinoma (Figure 2). Therefore, the animal model for HPV-16-derived tumors used in this study is suitable to evaluate the anticancer properties of AE.

In this report, the anticancer properties of $\mathrm{AE}$ were determined using both in vitro and in vivo assessments. The cell growth assay was performed using four different types of cells: CaSki (HPV-16-positive), HeLa (HPV-18-positive), HepG2, and HDFs. The results of the MTT assay, which depends on mitochondrial enzymatic activity in viable cells, indicated that the growth-inhibitory effects of AE on each cell type are dose-dependent, as shown in Figure 1. In Table 1, a nonlinear regression equation (fitting logistic sigmoidal model) was used to determine that the mean $\mathrm{IC}_{50}$ value obtained in CaSki cells was significantly less than the $\mathrm{IC}_{50}$ value in HDF cells $(P<0.01)$ after 48 hours in the presence of AE. However, the crude extract of AE did not demonstrate significant growth inhibition in HeLa or HepG2 cells, as indicated by the fact that both $\mathrm{IC}_{50}$ mean values showed no significant difference compared with the $\mathrm{IC}_{50}$ mean values of HDFs ( $P<0.1$ and $P<0.69$, respectively).

These results are similar to those of a previous study conducted by Siripong et al, ${ }^{33}$ in which it was reported that the aqueous extract of $\mathrm{AE}$ has weak antitumor activity against sarcoma-180 ascites cells in a transplanted ICR male mouse model. Moreover, in a study performed by Babu et al, ${ }^{29}$ it was found that the alcoholic extract of $A$. ilicifolius is cytotoxic towards the tumor cell line L-929 after a 72-hour treatment, but not after only 3 hours of treatment. 

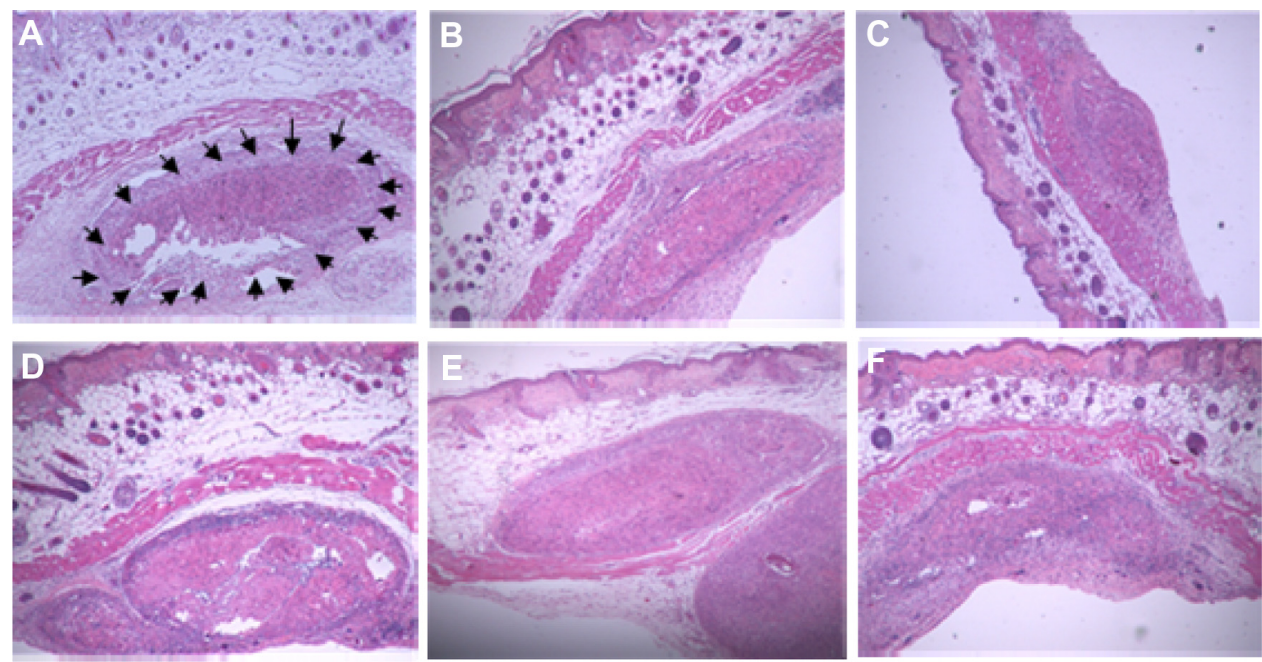

Figure 2 (A-F) Histological images of subcutaneous tumor nodules taken from nude mice implanted with CaSki cells. (A) Arrows indicate the malignant tumor present in the deep portion of the skin of I4-day HPV-Veh mice (×4). Tumor area of I4-day HPV-300AE (B), I4-day HPV-3000AE (C), 28-day HPV-Veh (D), 28-day HPV-300AE (E), and 28-day HPV-3000AE (F) $(\times 4)$.

Abbreviations: HPV, human papillomavirus; Veh, vehicle; AE, Acanthus ebracteatus Vahl crude extract.

Several in vitro studies have described the antitumor and antiproliferative properties of AE crude extract, ${ }^{33,34}$ as well as its active compounds, such as $\beta$-sitosterol, stigmasterol, lupeol, ${ }^{38}$ and benzoxazoline-2-one, ${ }^{37}$ on various types of cancer cells. In
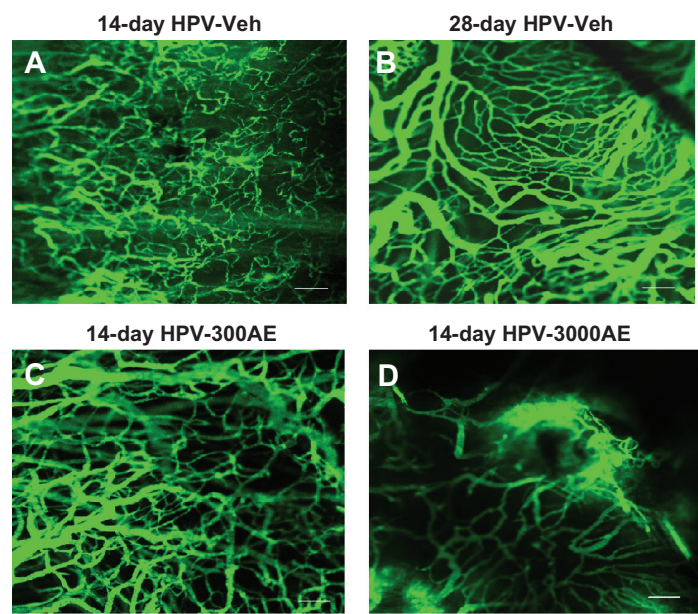

28-day HPV-300AE
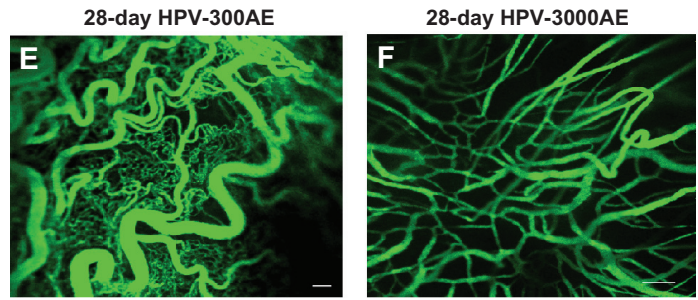

Figure 3 (A-F) Confocal laser microscopic images of the tumor microvascular network taken on day 14 in the HPV-Veh group (A), day 28 in the HPV-Veh group (B), day 14 in the HPV-300AE (300 mg/kg body weight) group (C), day 14 in the HPV$3000 \mathrm{AE}(3000 \mathrm{mg} / \mathrm{kg}$ body weight) group (D) day 28 in the HPV-300AE group (E) and day 28 in the HPV-3000AE group (F). The microvascular network was visualized using fluorescein isothiocyanate-labeled dextran fluorescence (MW 200000), with Acanthus ebracteatus Vahl crude extract; low magnification $\times 10$, bar $=50 \mu \mathrm{m}$.

Abbreviations: HPV, human papillomavirus; Veh, vehicle; AE, Acanthus ebracteatus Vahl crude extract. particular, $\beta$-sitosterol, which is the most common dietary phytosterol, is a highly concentrated constituent of $A E$ and may be a potential candidate for cancer chemotherapy. Several studies have demonstrated that $\beta$-sitosterol-induced apoptosis occurs through caspase- 3 activation. Additionally, $\beta$-sitosterol-induced apoptosis in MCA-102 tumor cells via alteration of p53 and p21 resulted in decreased expression of antiapoptotic Bcl-2 and increased expression of proapoptotic Bax. ${ }^{45,46}$

Furthermore, the report by Phisalaphong et $\mathrm{al}^{35}$ indicated that the weak antiproliferative effect of AE could be enhanced by its desalted product. This group reported an $\mathrm{IC}_{50}$ value of $3500 \mu \mathrm{g} / \mathrm{mL}$ after 48 hours' incubation, which is much lower than the $\mathrm{IC}_{50}$ value we observed $(6419.50 \pm 2282.62 \mu \mathrm{g} / \mathrm{mL})$ when the same HeLa cancer cell type was used. In the future, modification processes, including the isolation of the active ingredients in $\mathrm{AE}$, may be necessary to improve the efficacy of AE crude extract.

\section{Antiangiogenic activity of $\mathrm{AE}$}

This is the first time that a CaSki (HPV-16) cervical cancer mouse model was used to determine the potential of AE to inhibit angiogenesis. As shown in Figure 3, the capillary density was markedly increased around the tumor-bearing site. It is well known that angiogenesis is an important process involved in all stages of cervical cancer development. ${ }^{8-12,47-49}$ Confocal scanning laser fluorescence micrographs were used to generate microvascular networking images. The images revealed that newly formed capillaries could be identified by particular characteristics, such as increased permeability, increased diameter, and high tortuosity. ${ }^{42}$ In Figure 4, 


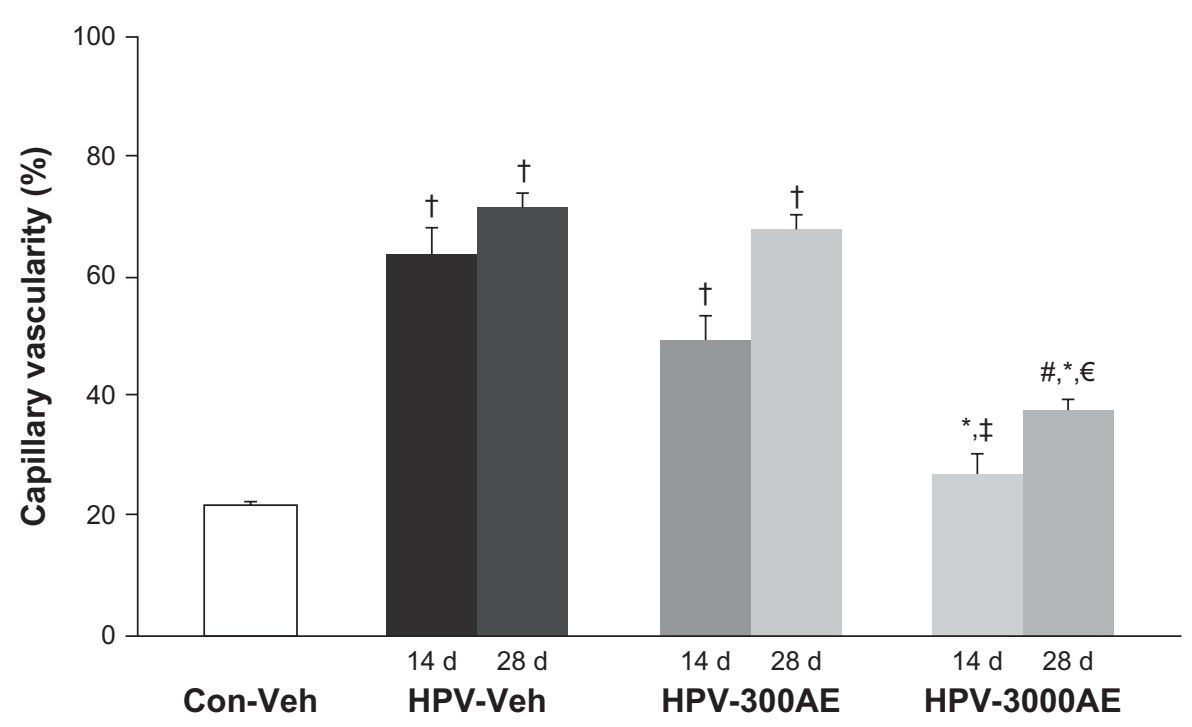

Figure 4 The percentages of capillary vascularity (mean \pm SE) on day 14 and day 28 after vehicle (distilled water) or AE (300 and 3,000 mg/kg BW) treatments, shown for control and HPV groups.

Notes: †Significantly different from control group $(P<0.00 \mathrm{I})$; " Significantly different from control group $(P<0.005)$; "Significantly different from HPV-Veh group $(P<0.00 \mathrm{I})$; ‡significantly different from HPV-300AE group $(P<0.001)$; $€$ Significantly different from HPV-300AE group $(P<0.01)$.

Abbreviations: Con, control; Veh, vehicle; HPV, human papillomavirus; AE, Acanthus ebracteatus Vahl crude extract; d, day.

the high-dose $(3000 \mathrm{mg} / \mathrm{kg})$ treatment of AE induced a significant decrease in the tumor $\mathrm{CV}$ on both day 14 and day $28(P<0.05)$.

In Figure 5 and Table 3, the results of VEGF expression indicate that CaSki-implanted mice had significantly greater
VEGF expression than the control mice. Interestingly, these data also indicate that $\mathrm{AE}$ crude extract can inhibit VEGF expression in a dose-dependent manner.

In addition, when the means of the $\% \mathrm{CV}$ values and the VEGF expression values for each group were plotted, they
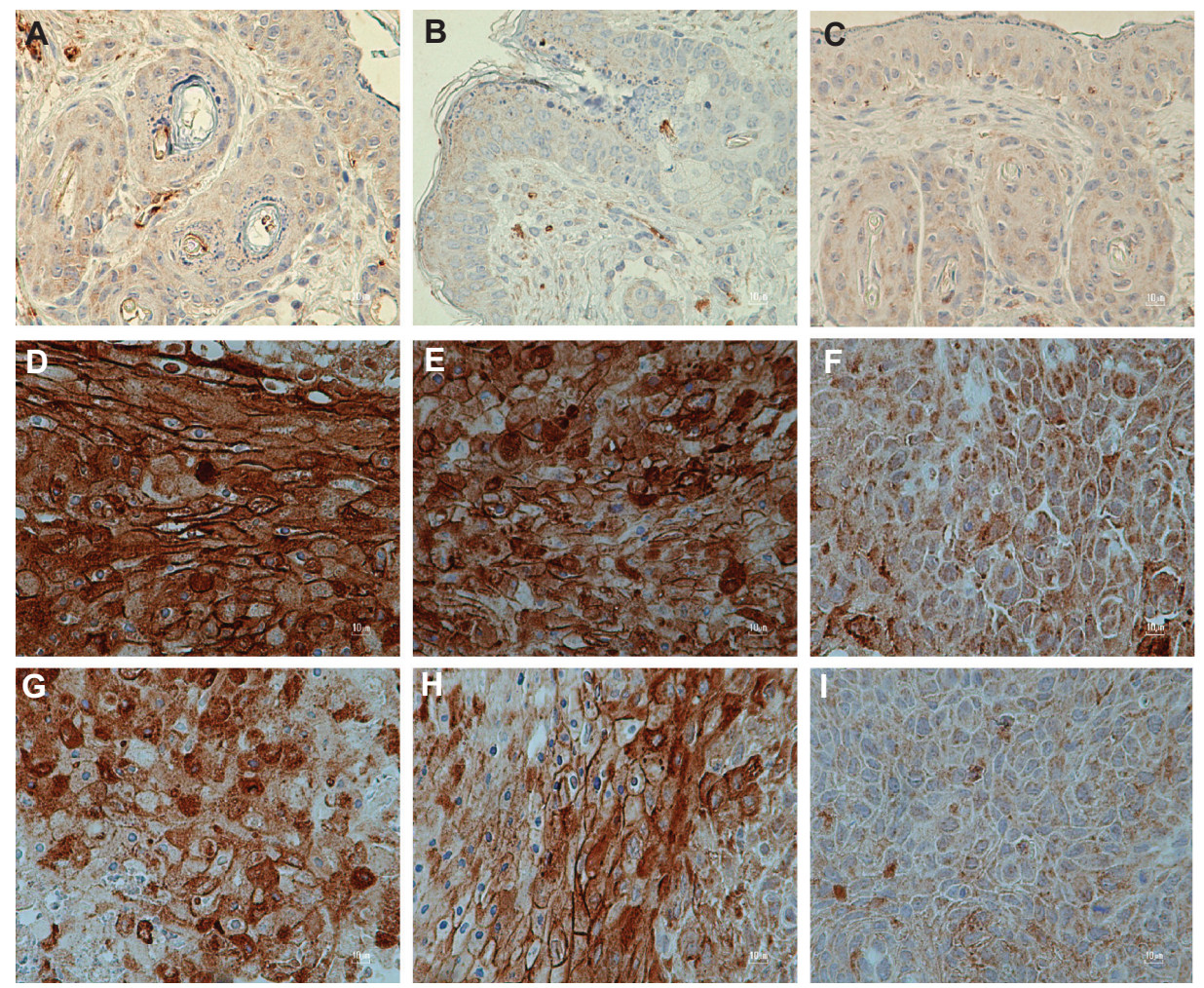

Figure 5 (A-I) The expression of vascular endothelial growth factor from Con-Veh (A), Con -300AE (B), Con -3000AE (C), I4- day human papillomavirus (HPV)-Veh (D), 14-day HPV-300AE (E), I4-day HPV-3000AE (F), 28-day HPV-Veh (G), 28-day HPV-300AE (H), and 28-day HPV-3000AE (I) (magnification $\times$ 40). Abbreviations: Con, control; Veh, vehicle; HPV, human papillomavirus; AE, Acanthus ebracteatus Vahl crude extract. 
Table 3 Vascular endothelial growth factor (VEGF) expression in tumor tissue area (\%) was determined from nude mice implanted with CaSki cells, with or without AE treatment at day 14 or day 28

\begin{tabular}{lll}
\hline Groups & \multicolumn{2}{l}{$\begin{array}{l}\text { Area of tumor tissue VEGF expression } \\
(\%) / \text { days after treatment }\end{array}$} \\
\cline { 2 - 3 } & At day I4 & At day 28 \\
\hline Con-Veh $(n=8)$ & $32.89 \pm 2.06(n=4)$ & $33.17 \pm 1.12(n=4)$ \\
Con-300AE $(n=10)$ & $29.64 \pm 2.22(n=5)^{n s}$ & $37.26 \pm 1.49(n=5)^{n s}$ \\
Con-3000AE $(n=8)$ & $40.40 \pm 3.47(n=4)^{n s}$ & $35.17 \pm 3.05(n=4)^{n s}$ \\
HPV-Veh $(n=9)$ & $80.96 \pm 2.16(n=5)^{\dagger}$ & $80.56 \pm 1.09(n=4)^{\dagger}$ \\
HPV-300AE $(n=7)$ & $77.33 \pm 3.87(n=3)^{\dagger}$ & $77.99 \pm 2.30(n=4)^{\dagger}$ \\
HPV-3000AE $(n=9)$ & $54.64 \pm 3.59(n=5)^{\dagger, \epsilon, \neq}$ & $45.63 \pm 3.47(n=4)^{€, \neq}$ \\
\hline
\end{tabular}

Notes: Significantly different than Con-Veh group $(P<0.001)$; ${ }^{\epsilon}$ Significantly different than HPV-Veh group $(P<0.001)$; ; Significantly different than HPV-300AE group $(P<0.001)$; ${ }^{n}$ Nonsignificant difference compared with Con-Veh group $(P<0.05)$. Data expressed as the mean \pm standard error of mean.

Abbreviations: VEGF, vascular endothelial growth factor; Con, control; Veh, vehicle; HPV, human papillomavirus; AE, Acanthus ebracteatus Vahl crude extract.

exhibited a linear relationship with a correlation coefficient of $r^{2}=0.82(P<0.05)$ (Figure 6A). This result suggests that the reduction in tumor capillary vascularity was linearly correlated with the increase in VEGF expression during tumor angiogenesis. Thus, the inhibitory effect of $\mathrm{AE}$ on angiogenesis is likely related to its ability to inhibit VEGF expression.

This result is consistent with the results generated by measuring tumor volumes, which indicated that $3000 \mathrm{AE}$ could suppress tumor growth significantly, as shown in Table 1. In Figure 2, the results of histological examination taken from each group appear to support the difference between tumor volumes as well.

In Figure 6B, the mean values of $\% \mathrm{CV}$ and tumor volume for every group were determined and discovered to possess a linear relationship with each other, with a correlation coefficient of $r^{2}=0.52(P<0.07)$. This result suggested that the reduction in tumor capillary vascularity was linearly correlated with the decrease in tumor volume. This relationship implies that the antiangiogenic activity of high-dose AE may inhibit the synthesis of new blood vessels that supply cervical cancer cells, resulting in a lack of nutrients and oxygen, which then suppresses tumor growth.

Using an in vivo model, we have demonstrated for the first time that $\mathrm{AE}$ crude extract is an efficacious inhibitor of angiogenesis. This study demonstrated that HPV-16 cervical cancer neocapillarization was significantly reduced by a high-dose treatment of AE crude extract ( $3000 \mathrm{mg} / \mathrm{kg}$ body weight).

It is believed that the major mechanism by which cervical cancer induces angiogenesis involves a hypoxia-mediated angiogenic switch. It has also been reported that the dysregulation of 553 is involved in the activation of proangiogenic factors such as VEGF and HIF-1 $\alpha .{ }^{19,50}$ Recent studies have identified a number of additional cellular targets of E6. The inactivation of active p53 protein is most likely an important element of E6-induced cellular transformation in cervical cancer. The E6 oncoprotein is not only an important factor in HPV-associated carcinogenesis but is also directly involved in the angiogenic process. The present study demonstrated that the mechanism by which $\mathrm{AE}$ inhibits angiogenesis is related to its ability to inhibit VEGF expression. Therefore, the effect of AE on the E6 oncoprotein may need to be confirmed in the future.

Other properties of $\mathrm{AE}$, including its anti-inflammatory and antioxidative activities, may participate in the induction of tumor apoptosis and/or the inhibition of tumor angiogenesis..$^{21,51-54}$ Therefore, in addition to its antitumor properties, the antioxidative activity of $\mathrm{AE}$ might provide additional benefits.
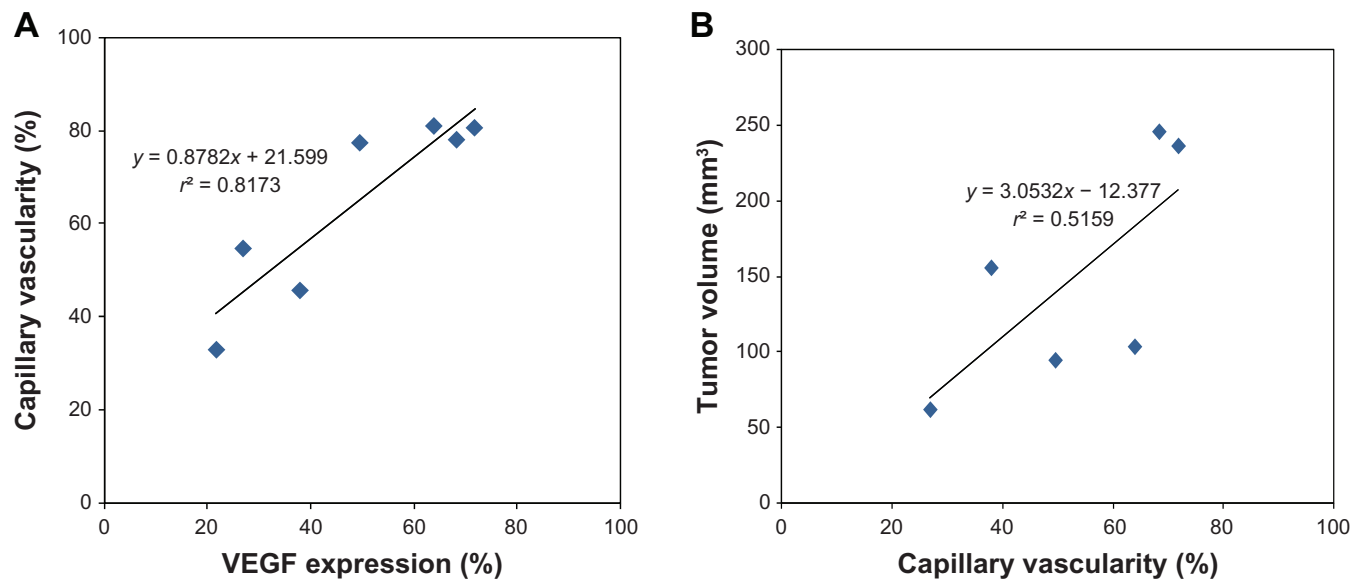

Figure 6 (A) Plots of \% vascular endothelial growth factor (VEGF) expression vs \% capillary vascularity (CV). The solid line represents the correlation between VEGF and CV. The correlation is expressed by $y=0.8782 x+21.599, r^{2}=0.82$. (B) Plots of \%CV vs \% tumor volume. The solid line represents the correlation between capillary vascularity and tumor volume. The correlation is expressed by $y=3.0532 x-12.377, r^{2}=0.52$

Abbreviations: VEGF, vascular endothelial growth factor; CV, capillary vascularity. 


\section{Conclusion}

In summary, our studies demonstrated that the AE crude extract could inhibit tumor growth and tumor angiogenesis in a mouse model of HPV-16-derived cervical cancer. In particular, the antiangiogenic activity of AE was significantly correlated with its ability to inhibit VEGF expression, providing a potential mechanism to explain the antitumor effects of AE.

\section{Acknowledgments}

This study was supported by Ratchadapisek-Sompoch research fund, Chulalongkorn University, and The National Research Council of Thailand (no GRB 047523017).

\section{Disclosure}

The authors declare that they have no competing interests related to this study.

\section{References}

1. Parkin DM, Bray F, Ferlay J, Pisani P. Global cancer statistics, 2002. CA Cancer J Clin. 2005;55(2):74-108.

2. Kjaer SK, Tran TN, Sparen P, et al. The burden of genital warts: a study of nearly 70,000 women from the general female population in the 4 Nordic countries. J Infect Dis. 2007;196(10):1447-1454.

3. Schiffman M, Castle PE, Jeronimo J, Rodriguez AC, Wacholder S. Human papillomavirus and cervical cancer. Lancet. 2007;370(9590): 890-907.

4. zur Hausen H. Viruses in human cancers. Science. 1991;254(5035): $1167-1173$.

5. Doorbar J. Molecular biology of human papillomavirus infection and cervical cancer. Clin Sci (Lond). 2006;110(5):525-541.

6. Munoz N, Castellsague X, de Gonzalez AB, Gissmann L. Chapter 1: HPV in the etiology of human cancer. Vaccine. 2006;24 Suppl 3: S3/1-10.

7. Prendiville W, Davies P. The Health Professional's HPV Handbook 1: Human Papillomavirus and Cervical Cancer. London: Informa Healthcare; 2006.

8. Van Trappen PO, Steele D, Lowe DG, et al. Expression of vascular endothelial growth factor (VEGF)-C and VEGF-D, and their receptor VEGFR-3, during different stages of cervical carcinogenesis. J Pathol. 2003;201(4):544-554.

9. No JH, Jo H, Kim SH, et al. Expression of vascular endothelial growth factor and hypoxia inducible factor-1alpha in cervical neoplasia. Ann NY Acad Sci. 2009;1171:105-110.

10. Guidi AJ, Abu-Jawdeh G, Berse B, et al. Vascular permeability factor (vascular endothelial growth factor) expression and angiogenesis in cervical neoplasia. J Natl Cancer Inst. 1995;87(16):1237-1245.

11. Dobbs SP, Hewett PW, Johnson IR, Carmichael J, Murray JC. Angiogenesis is associated with vascular endothelial growth factor expression in cervical intraepithelial neoplasia. Br J Cancer. 1997; 76(11):1410-1415.

12. Hammes LS, Tekmal RR, Naud P, et al. Up-regulation of VEGF, c-fms and COX-2 expression correlates with severity of cervical cancer precursor (CIN) lesions and invasive disease. Gynecol Oncol. 2008;110(3): $445-451$.

13. Kodama J, Seki N, Tokumo K, et al. Vascular endothelial growth factor is implicated in early invasion in cervical cancer. Eur J Cancer. 1999; 35(3):485-489.
14. Yu H, Zhang S, Zhang R, Zhang L. The role of VEGF-C/D and Flt-4 in the lymphatic metastasis of early-stage invasive cervical carcinoma. J Exp Clin Cancer Res. 2009;28:98.

15. Monk BJ, Willmott LJ, Sumner DA. Anti-angiogenesis agents in metastatic or recurrent cervical cancer. Gynecol Oncol. 2010;116(2): 181-186.

16. Bequet-Romero M, Lopez-Ocejo O. Angiogenesis modulators expression in culture cell lines positives for HPV-16 oncoproteins. Biochem Biophys Res Commun. 2000;277(1):55-61.

17. Lopez-Ocejo O, Viloria-Petit A, Bequet-Romero M, Mukhopadhyay D, Rak J, Kerbel RS. Oncogenes and tumor angiogenesis: the HPV-16 E6 oncoprotein activates the vascular endothelial growth factor (VEGF) gene promoter in a p53 independent manner. Oncogene. 2000;19(40): 4611-4620.

18. Tang X, Zhang Q, Nishitani J, Brown J, Shi S, Le AD. Overexpression of human papillomavirus type 16 oncoproteins enhances hypoxiainducible factor 1 alpha protein accumulation and vascular endothelial growth factor expression in human cervical carcinoma cells. Clin Cancer Res. 2007;13(9):2568-2576.

19. Willmott LJ, Monk BJ. Cervical cancer therapy: current, future and antiangiogensis targeted treatment. Expert Rev Anticancer Ther. 2009;9(7): 895-903.

20. Tiwari KP, Minicha PK, Masood M. Acanthicifoline - a new alkaloid from Acanthus ilicifolius. Pol J Chem. 1980;54:857-858.

21. Minocha PK, Tiwari KP. A triterpenoidal saponin from roots of Acanthus illicifolius. Phytochemistry. 1981;20(1):135-137.

22. Jensen HFW, Jensen SR, Nielsen BJ. Chemotaxonomy of the acanthaceae. Iridoids and quaternary amines. Phytochemistry. 1988;27(8): 2581-2589.

23. Hokputsa S, Harding SE, Inngjerdingen K, et al. Bioactive polysaccharides from the stems of the Thai medicinal plant Acanthus ebracteatus: their chemical and physical features. Carbohydr Res. 2004;339(4): 753-762.

24. Kanchanapoom T, Kasai R, Picheansoonthon C, Yamasaki K. Megastigmane, aliphatic alcohol and benzoxazinoid glycosides from Acanthus ebracteatus. Phytochemistry. 2001;58(5):811-817.

25. Sittiwet C, Niamsa N, Puangpronpitag D. Antimicrobial activity of Acanthus ebracteatus Vahl aqueous extract: the potential for skin infection treatment. Int J Biol Chem. 2009;3:95-98.

26. Masathien C, Siripong P. In vitro immunopotentiating effect(s) of Acanthus ebracteatus Vahl roots on human lymphocytes. J Med Technol Assoc Thailand. 1991;15:97-103.

27. Babu BH, Shylesh BS, Padikkala J. Antioxidant and hepatoprotective effect of Acanthus ilicifolius. Fitoterapia. 2001;72(3):272-277.

28. Advani SB, Sam J. Potential anticancer and antiviral agents. Substituted 3 - $\left[1^{\prime}\left(2^{\prime}, 3^{\prime}, 4^{\prime}\right.\right.$-tri- $O$-benzoyl- $\beta$-d-ribopyranosyl)]-2-benzoxazolinones. $J$ Heterocycl Chem. 1968;5(1):119-122.

29. Babu BH, Shylesh BS, Padikkala J. Tumour reducing and anticarcinogenic activity of Acanthus ilicifolius in mice. J Ethnopharmacol. 2002;79(1):27-33.

30. Wu J, Zhang S, Xiao Q, et al. Megastigmane and flavone glycosides from Acanthus ilicifolius. Pharmazie. 2003;58(5):363-364.

31. Laupattarakasem P, Houghton PJ, Hoult JR, Itharat A. An evaluation of the activity related to inflammation of four plants used in Thailand to treat arthritis. J Ethnopharmacol. 2003;85(2-3):207-215.

32. Srivatanakul P, Naka L. Effect of Acanthus ilicifolius Linn. in treatment of leukemic mice. Thai Cancer J. 1981;7:89-93.

33. Siripong P, Kongkathip B, Kanokmedhakul K, Hitosuyanagi Y, Takeya K, Itokawa H. Study on antitumor potential of Acanthus ebracteatus Vahl roots. Thai Cancer J. 1998;24(29-37):29.

34. Tiwawech D, Siripong P, Kupradinun P. Inhibition of diethylnitrosamine (DEN)-induced hepatic foci by pre and post treatment with Acanthus ebracteatus Vahl in rats. Thai Cancer J. 1993;1-2:7-13.

35. Phisalaphong M, Thu Ha N, Siripong P. Desalting of aqueous extract of Acanthus ebracteatus Vahl by nanofiltration. Sep Sci Technol. 2006;41(3):455-470. 
36. Moon DO, Lee KJ, Choi YH, Kim GY. Beta-sitosterol-induced-apoptosis is mediated by the activation of ERK and the downregulation of Akt in MCA-102 murine fibrosarcoma cells. Int Immunopharmacol. 2007;7(8):1044-1053.

37. Kokpol U, Chittawong V, Miles DH. Chemical constituents of the roots of Acanthus illicifolius. J Nat Prod. 1986;49(2):355-356.

38. Hartwell JL. Types of anticancer agents isolated from plants. Cancer Treat Rep. 1976;60(8):1031-1067.

39. Handa SS, Khanuja SPS, Longo G, Rakesh DD. Extraction Technologies for Medicinal and Aromatic Plants. Trieste: International Centre for Science and High Technology; 2008:266.

40. Lertworapreecha M, Patumraj S, Niruthisard S, Hansasuta P, Bhattarakosol P. Mouse acquired HPV tumor using dorsal skin-fold window chamber. Indian J Exp Biol. 2009;47(5):327-332.

41. Viboolvorakul S, Niimi H, Wongeak-in N, Eksakulkla S, Patumraj S. Increased capillary vascularity in the femur of aged rats by exercise training. Microvasc Res. 2009;78(3):459-463.

42. Patumraj S, Yoysungnoen P, Kachonrattanadet P, Wirachwong P. Tumor neocapillary density in hepatocellular carcinoma cells implanted nude mice model. Clin Hemorheol Microcirc. 2005;33(2):137-144.

43. Tomayko MM, Reynolds CP. Determination of subcutaneous tumor size in athymic (nude) mice. Cancer Chemother Pharmacol. 1989;24(3): $148-154$.

44. Fok TCO, Jan A, Peel SAF, Evans AW, Clokie CML, Sándor GKB Hyperbaric oxygen results in increased vascular endothelial growth factor (VEGF) protein expression in rabbit calvarial critical-sized defects. Oral Surg Oral Med Oral Pathol Oral Radiol Endod. 2008;105(4): 417-422.

45. Choi YH, Kong KR, Kim YA, et al. Induction of Bax and activation of caspases during beta-sitosterol-mediated apoptosis in human colon cancer cells. Int J Oncol. 2003;23(6):1657-1662.
46. Awad AB, Roy R, Fink CS. Beta-sitosterol, a plant sterol, induces apoptosis and activates key caspases in MDA-MB-231 human breast cancer cells. Oncol Rep. 2003;10(2):497-500.

47. Triratanachat S, Niruthisard S, Trivijitsilp P, Tresukosol D, Jarurak N. Angiogenesis in cervical intraepithelial neoplasia and early-staged uterine cervical squamous cell carcinoma: clinical significance. Int $J$ Gynecol Cancer. 2006;16(2):575-580.

48. Obermair A, Bancher-Todesca D, Bilgi S, et al. Correlation of vascular endothelial growth factor expression and microvessel density in cervical intraepithelial neoplasia. J Natl Cancer Inst. 1997;89(16): 1212-1217.

49. Smith-McCune K, Zhu YH, Hanahan D, Arbeit J. Cross-species comparison of angiogenesis during the premalignant stages of squamous carcinogenesis in the human cervix and K14-HPV16 transgenic mice. Cancer Res. 1997;57(7):1294-1300.

50. Nakamura M, Bodily JM, Beglin M, Kyo S, Inoue M, Laimins LA. Hypoxia-specific stabilization of HIF-1 alpha by human papillomaviruses. Virology. 2009;387(2):442-448.

51. Agshikar NV, Naik VR, Abraham GJ, Reddy CV, Naqvo SW, Mittal PK. Analgesic anti-inflammatory activity of Acanthus illicifolius Linn. Indian J Exp Biol. 1979;17(11):1257-1258.

52. Liu M, Pelling JC, Ju J, Chu E, Brash DE. Antioxidant action via p53-mediated apoptosis. Cancer Res. 1998;58(8):1723-1729.

53. Maity P, Chakraborty S, Bhattacharya P. Neovascularisation offers a new perspective to glutamine related therapy. Indian J Exp Biol. 2000; 38(1):88-90.

54. Nguyen P, Ho CL, Teo SS, Harikrishna J, Rahim R. Sequence and transcript analyses of antioxidant genes from Acanthus ebracteatus Vahl. Tree Genet Genomes. 2008;4(4):705-713.
Cancer Management and Research

\section{Publish your work in this journal}

Cancer Management and Research is an international, peer-reviewed open access journal focusing on cancer research and the optimal use of preventative and integrated treatment interventions to achieve improved outcomes, enhanced survival and quality of life for the cancer patient The journal welcomes original research, clinical \& epidemiological

\section{Dovepress}

studies, reviews \& evaluations, guidelines, expert opinion \& commentary, case reports \& extended reports. The manuscript management system is completely online and includes a very quick and fair peerreview system, which is all easy to use. Visit http://www.dovepress.com/ testimonials.php to read real quotes from published authors. 